University of New Hampshire

University of New Hampshire Scholars' Repository

$10-27-2008$

\title{
Trends in wintertime climate in the northeastern United States: 1965-2005
}

\author{
Elizabeth A. Burakowski \\ University of New Hampshire - Main Campus, elizabeth.burakowski@unh.edu \\ Cameron P. Wake \\ University of New Hampshire - Main Campus, cameron.wake@unh.edu \\ Rob Braswell \\ University of New Hampshire - Main Campus, rob.braswell@unh.edu \\ David R. Brown \\ Louisiana State University at Baton Rouge
}

Follow this and additional works at: https://scholars.unh.edu/earthsci_facpub

\section{Recommended Citation}

Burakowski, E. A., C. P. Wake, B. Braswell, and D. P. Brown (2008), Trends in wintertime climate in the northeastern United States: 1965-2005, J. Geophys. Res., 113, D20114, doi:10.1029/2008JD009870.

This Article is brought to you for free and open access by the Earth Sciences at University of New Hampshire Scholars' Repository. It has been accepted for inclusion in Earth Sciences Scholarship by an authorized administrator of University of New Hampshire Scholars' Repository. For more information, please contact Scholarly.Communication@unh.edu. 


\title{
Trends in wintertime climate in the northeastern United States: 1965-2005
}

\author{
Elizabeth A. Burakowski, ${ }^{1}$ Cameron P. Wake, ${ }^{1}$ Bobby Braswell, ${ }^{2}$ and David P. Brown ${ }^{3}$ \\ Received 25 January 2008; revised 24 June 2008; accepted 23 July 2008; published 28 October 2008.
}

[1] Humans experience climate variability and climate change primarily through changes in weather at local and regional scales. One of the most effective means to track these changes is through detailed analysis of meteorological data. In this work, monthly and seasonal trends in recent winter climate of the northeastern United States (NE-US) are documented. Snow cover and snowfall are important components of the region's hydrological systems, ecosystems, infrastructure, travel safety, and winter tourism and recreation. Temperature, snowfall, and snow depth data were collected from the merged United States Historical Climate Network (USHCN) and National Climatic Data Center Cooperative Network (COOP) data set for the months of December through March, 1965-2005. Monthly and seasonal time series of snow-covered days (snow depth $>2.54 \mathrm{~cm}$ ) are constructed from daily snow depth data. Spatial coherence analysis is used to address data quality issues with daily snowfall and snow depth data, and to remove stations with nonclimatic influences from the regional analysis. Monthly and seasonal trends in mean, minimum, and maximum temperature, total snowfall, and snow-covered days are evaluated over the period 1965-2005, a period during which global temperature records and regional indicators exhibit a shift to warmer climate conditions. NE-US regional winter mean, minimum, and maximum temperatures are all increasing at a rate ranging from $0.42^{\circ}$ to $0.46^{\circ} \mathrm{C} /$ decade with the greatest warming in all three variables occurring in the coldest months of winter (January and February). The regional average reduction in number of snow-covered days in winter $(-8.9 \mathrm{~d} /$ decade $)$ is also greatest during the months of January and February. Further analysis with additional regional climate modeling is required to better investigate the causal link between the increases in temperature and reduction in snow cover during the coldest winter months of January and February. In addition, regionally averaged winter snowfall has decreased by about $4.6 \mathrm{~cm} /$ decade, with the greatest decreases in snowfall occurring in December and February. These results have important implications for the impacts of regional climate change on the northeastern United States hydrology, natural ecosystems, and economy.

Citation: Burakowski, E. A., C. P. Wake, B. Braswell, and D. P. Brown (2008), Trends in wintertime climate in the northeastern United States: 1965-2005, J. Geophys. Res., 113, D20114, doi:10.1029/2008JD009870.

\section{Introduction}

[2] Surface air temperature measurements compiled for the past 150 years show that global and northern hemisphere surface temperatures have increased over the last century, and that the rate of warming has increased over the past three to four decades [e.g., Brohan et al., 2006; Hansen et al., 2006]. Detailed analysis has shown that global

\footnotetext{
${ }^{1}$ Climate Change Research Center, Institute for the Study of Earth, Oceans, and Space, and Department of Earth Sciences, University of New Hampshire, Durham, New Hampshire, USA.

${ }^{2}$ Complex Systems Research Center, Institute for the Study of Earth, Oceans, and Space, University of New Hampshire, Durham, New Hampshire, USA.

${ }^{3}$ Department of Geography and Anthropology, Louisiana State University, Baton Rouge, Louisiana, USA.
}

Copyright 2008 by the American Geophysical Union. 0148-0227/08/2008JD009870 temperature increases since 1970 are being driven primarily by enhanced levels of greenhouse gases in the atmosphere that originate from the burning of fossil fuel and land use changes, and that the eleven warmest years in the global instrumental temperature record (since 1850) have occurred since 1995 [Solomon et al., 2007].

[3] Recent warming of surface air temperatures across New England has been well documented [Keim et al., 2003; Trombulak and Wolfson, 2004]. For the northeastern United States over the period 1970-1999, the rate of winter warming was $0.70^{\circ} \mathrm{C} /$ decade, greater than any other seasonal rate of warming, and significantly greater than $0.12^{\circ} \mathrm{C} /$ decade winter warming over the period $1900-$ 1999 [Hayhoe et al., 2007]. Analysis of snow to total precipitation $(\mathrm{S} / \mathrm{P})$ ratios in northern New England over the period 1949-2000 indicates that most of the 0.30 to 0.23 decrease in S/P ratio has occurred since 1975 [Huntington and Hodgkins, 2004]. Trends in other hydrologic and climate 
indicators, such as the timing of lake ice-out [Hodgkins et al., 2002], timing of annual winter/spring high river flows [Hodgkins et al., 2003], and river ice thickness [Huntington et al., 2003], also exhibit a coherent warming shift in the during the 1970s, as do changes in the spring date for lilac blooms in the northeast, and grape and apple blooms in New York state [Wolfe et al., 2005]. In addition, monthly mean river runoff showed increasing trends over the same period during the winter months of January, February, and March, which is consistent with the advancement in the date of winter/spring high river flows [Hodgkins and Dudley, 2006b].

[4] Across North America, a significant decrease in winter snow cover extent derived from surface observations over the period 1960-2000 is likely the result of earlier spring melt [Dyer and Mote, 2006] and a decrease in the extent of deeper snowpacks [Dyer and Mote, 2006; Brown, 2000]. Warmer spring temperatures are linked to significant reductions in midlatitude northern hemisphere snow cover extent (SCE) from 1966 to 2005 during the months of March and April, as identified from satellite-based data [Lemke et al., 2007]. In addition, analysis of weekly satellite snow maps indicate that a poleward amplification of decreasing northern hemisphere spring SCE is consistent with an enhanced snow-albedo feedback over northern latitudes over the period 1972-2006 [Déry and Brown, 2007].

[5] Longer term records, such as research by Leathers and Luff [1997] did not identify any significant trends in duration of snow cover $2.5 \mathrm{~cm}$ or greater over the period 1948-1988, which includes the relatively cool period of the 1960s. However, snow cover duration in the NE-US was found to be strongly correlated with temperature during that time period. Changes in snow cover can be an important indicator of climate change at the regional scale because of its strong influence on the surface radiation balance and its resulting impact on surface air temperatures [Lemke et al., 2007; Groisman et al., 1994]. Previous studies have shown that the presence of snow cover can decrease air surface temperatures more than $5^{\circ} \mathrm{C}$ [Dewey, 1977; Baker et al., 1992; Leathers and Robinson, 1993; Leathers et al., 1995]. The snow albedo feedback mechanism may play a significant role in winter warming in the NE-US, where snowpacks tend to be shallow.

[6] Warming winters in the NE-US have had a significant impact on the region's economy. For example, the northeast U.S. ski industry generates approximately three billion dollars per year in visitor spending and tax revenue [Scott and McBoyle, 2007], especially for mountainous states like New Hampshire, Vermont, and Maine, which all rank in the top ten states that benefit from winter skiing as a percentage of the state's economy [National Ski Areas Association, 2006]. Warmer winters with below average snowfall have reduced profit margins of ski resorts in the NE, which has led to the closure of many small resorts [Hamilton et al., 2003]. In addition, Hamilton et al. [2007] show that winter snow conditions in urban areas play a significant role in skier activity on a daily basis. New Hampshire, ranked in the top five states that benefit from the ski industry as a percentage of the state's economy, lost an average 13.1 million dollars from decreased sales of Alpine and Nordic ski tickets and snowmobile registrations during warm, slushy winters compared to cold, snowy winters
[Wake et al., 2006]. In the context of climate change and global warming, winter tourism and recreation in the NE-US will likely continue to experience negative economic impacts resulting from diminished snowfall and over successive years in response to increasing winter temperatures [Frumhoff et al., 2008; Scott and McBoyle, 2007].

[7] Global and regional records of temperature and other climate indicators indicate a coherent shift to warmer conditions around 1970. Detailed analysis of winter climate trends is essential to understanding the cause of recent winter warming, and to evaluate the potential impacts on the northeastern United States. In this study, we analyze winter climate trends in snowfall, temperature, and snow cover data over the period 1965-2005. To evaluate the robustness of recent winter warming trends and account for trend sensitivity of a start date that falls during a relatively cool year or period, seasonal and monthly trends are quantified using start dates ranging from 1965 to 1976 and end dates ranging from 1994 to 2005. Because snowfall and the number of snow-covered days (SCD) in March often exceed December snowfall and snow-covered days in this region, winter trends include the months of December, January, February and March.

\section{Data and Methods}

\subsection{Data Sources}

[8] For this study, the northeastern United States includes Connecticut, Maine, Massachusetts, New Hampshire, New Jersey, New York, Pennsylvania, Rhode Island, and Vermont (Figure 1). In order to maximize station density, daily snowfall, snow depth, and mean temperature data are compiled from two daily surface data sets containing observations collected at over 300 National Weather Service First Order stations and Cooperative Observer Program (COOP) stations in the northeastern United States over the period 1965-2005. The United States Historical Climate Network (USHCN) provides one high-quality daily data set, denoted as NDP-070, compiled by the National Climatic Data Center (NCDC), and is available for download at the Carbon Dioxide Information and Analysis Center (http:// cdiac.ornl.gov/ftp/ndp070/) [Easterling et al., 1999; Williams et al., 2006]. The second is the digitized COOP (DSI-3200) data set provided by the National Climatic Data Center (NCDC) is available for download from NCDC (http:// cdo.ncdc.noaa.gov/pls/plclimprod/poemain.accessrouter? datasetabbv+SOD). If a station was included in both data sets, the USHCN record was retained and the COOP record discarded.

[9] Monthly temperature records were obtained from the USHCN monthly data set NDP-019 [Karl et al., 1990; Easterling et al., 1999; Williams et al., 2005]. The records contain monthly averaged maximum, minimum, and mean temperature from 138 stations located in 38 NCDC climate divisions across the northeastern United States (Figure 1). Monthly data have been corrected for station relocations [Karl and Williams, 1987], instrument changes [Quayle et al., 1991], urbanization effects [Karl et al., 1988], and time of observation biases [Karl et al., 1986].

\subsection{Data Processing}

[10] The first step in data processing addresses data quality with respect to nonclimatic issues that can signifi- 


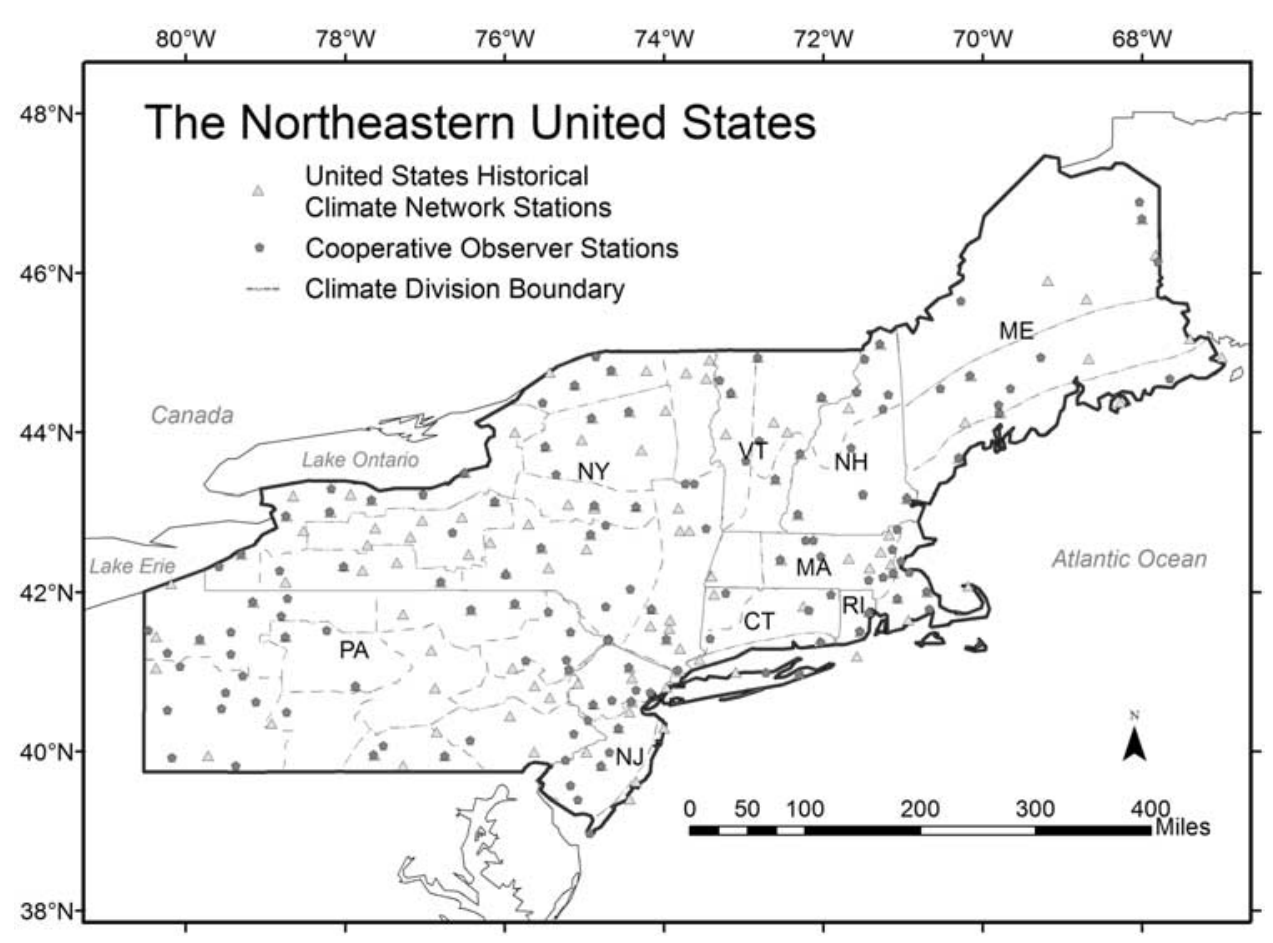

Figure 1. Distribution of northeastern United States climate stations used in this study. United States Historical Climate Network (USHCN) stations are shown as light gray triangles, and Cooperative (COOP) Network stations are shown as dark gray circles. National Climatic Data Center (NCDC) climate division boundaries within each state are delineated with dashed lines.

cantly influence trends identified in snowfall and snow depth (e.g., station moves, instrument changes, observer changes, or land-use changes). Observational practices are not consistent among USHCN and NWS stations, and can lead to discrepancies among nearby stations. For example, weather observers have the option of either measuring snowfall at 6-h intervals, clearing off the snowboard after each measurement. When compared to observers that measure snowfall only once daily, the 6-h snowboard practice has been known to result in higher snowfall totals [Doesken and Judson, 1996]. Other factors that can complicate trend analysis include gauge undercatch, compaction, and assumptions about snow density [Roebber et al., 2003; Kunkel et al., 2007]. The authors assume that discrepancies in observing practice are random and largely canceled out when an entire region is studied. The identification of biases introduced by such discrepancies is therefore of primary importance when analyzing snowfall trends. To address this, we analyze the data using a spatial coherence method developed and tested by Kunkel et al. [2007], which compares neighboring annual station anomalies to determine whether nonclimatic influences are introducing nonclimatic biases to the long-term record (see auxiliary material). ${ }^{1}$ The method assumes that nonclimatic influences, such as a change from 6-hourly to 24 -h observation practice, manifests itself as a shift in anomalies. Of the 168 stations with greater than $80 \%$ complete daily snowfall and SCD records, 88 snowfall stations and 123 SCD stations were found to pass for spatial coherence. While metadata

\footnotetext{
${ }^{1}$ Auxiliary materials are available in the HTML. doi:10.1029/ 2008JD009870.
}

station records can be useful in identifying the cause of the shifts identified using spatial coherence, many metadata records remain incomplete so the source of shifts were not routinely determined for many of the stations used in this study.

[11] The second step in data processing fills missing values in the 123-station spatially coherent SCD data set using the depth change (DC) method developed by Hughes and Robinson [1993] for stations with no more than $25 \%$ of their total winter snow depth values missing from a season. Missing snow depth values are filled sequentially in one of three ways. (1) If the daily mean temperature of the current day is greater than $5^{\circ} \mathrm{C}$, there is no recorded snowfall, and the previous day's snow depth was zero, then the missing day's value is filled with zero. (2) If the mean daily temperature for the current day is below $-10^{\circ} \mathrm{C}$ and snowfall is equal to zero, the current day's snow depth is set equal to the previous day's snow depth (this assumes no compaction of the snow on ground has occurred). (3) If the mean daily temperature is greater than $-10^{\circ} \mathrm{C}$ and less than $5^{\circ} \mathrm{C}$, the current day's snow depth is estimated to be the previous day's snow depth plus the current day's snowfall, less the change in snow depth as calculated from regional regression equations (see auxiliary material). The DC method was found to correctly predict the presence of snow cover greater than $2.5 \mathrm{~cm} 98 \%$ of the time for four regions within the northeastern United States in a binary crossvalidation matrix (see auxiliary material). About $5.7 \%$ of the daily values in the 123-station SCD data set are flagged as missing. The DC method was successfully used to fill less than $0.5 \%$ of the total daily snow depth values; the remaining $5.2 \%$ of the missing values were not infilled because of 

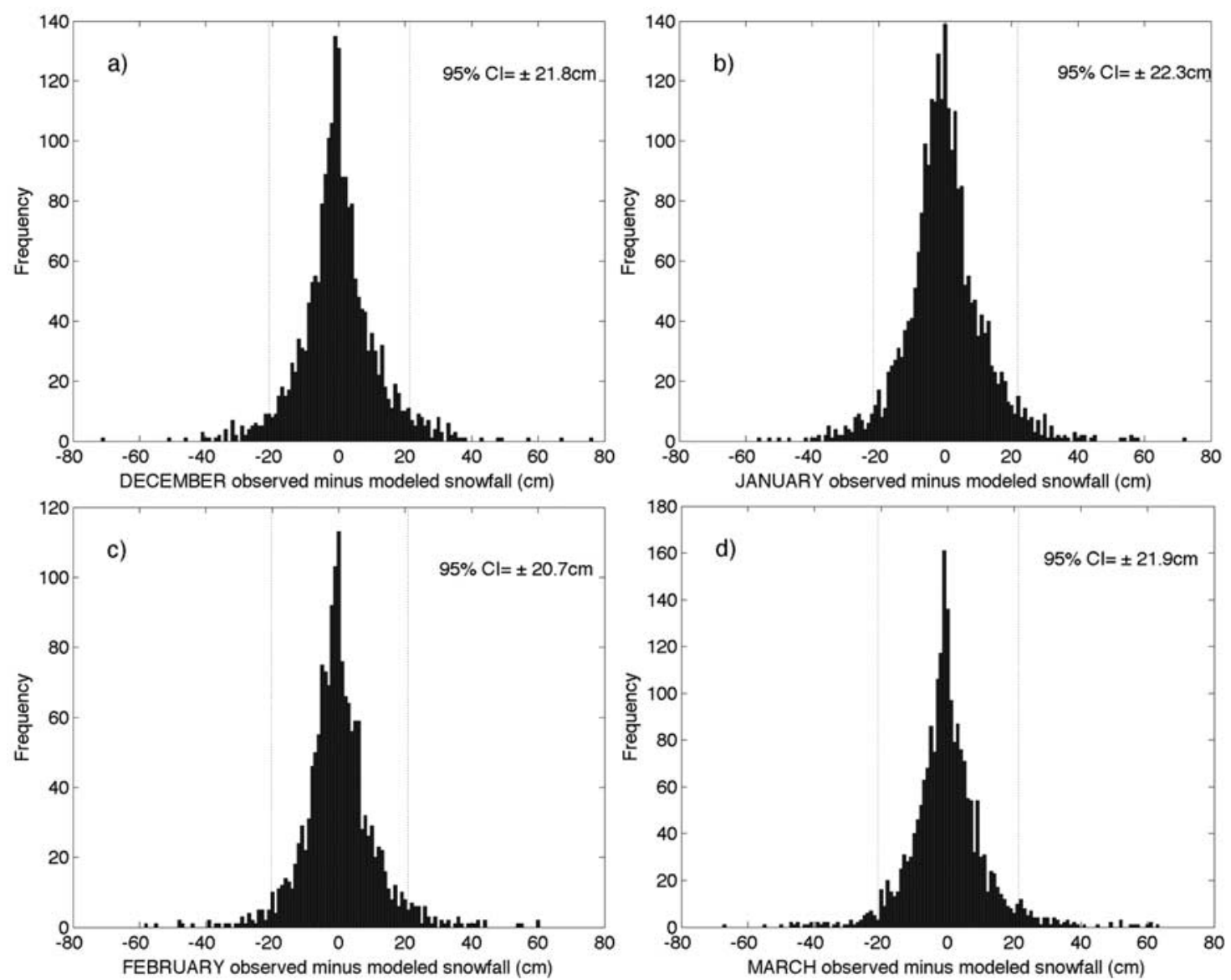

Figure 2. Observed minus modeled snowfall totals for (a) December, (b) January, (c) February, and (d) March. The $95 \%$ confidence intervals (thin vertical lines) are estimated as 2 standard deviations of the error residuals.

insufficient daily temperature, snowfall, or previous day's snow depth data.

[12] In the third step, using the 88 spatially coherent snowfall stations, monthly snowfall totals are flagged as missing for stations with more than $10 \%$ of daily observations missing from any given month. The missing monthly snowfall totals for stations with no more than 10 missing months over the period 1965-2005 are filled using a linear regression between the three nearest surrogate neighbors having a Pearson correlation greater than 0.7. On the basis of the range of $95 \%$ confidence intervals $( \pm 20.7 \mathrm{~cm}$ to $\pm 22.3 \mathrm{~cm}$ ) in cross validation, the monthly snowfall gapfilling model was chosen as an acceptable means to fill the missing data values (Figure 2). Less than $5 \%$ of the December-March snowfall totals required filling for the period 1965-2005. Using surrogate station linear regression, $3.1 \%$ of monthly total snowfall records were successfully filled. The remaining missing snowfall records (i.e., those with Pearson correlation $<0.7$ which represent $1.7 \%$ of the total monthly records) were subsequently filled using the primary station's 1965-2005 mean monthly snowfall total.

\subsection{Data Analysis}

[13] For each station, seasonal (December of one year through March of the following year) and monthly time series are computed for the following climate variables: (1) total snowfall, (2) snow-covered days (SCD) greater than $0 \mathrm{~cm}, 2.5 \mathrm{~cm}$ (1 inch), and $7.6 \mathrm{~cm}$ (3 inches) of snow depth, (3) minimum temperature, (4) maximum temperature, and (5) mean temperature. For snowfall and SCD, seasonal and monthly values were calculated for stations with fewer than $10 \%$ of daily values missing from any given winter or month to create the time series from 1965 to 2005 . The decadal rate of change in these wintertime climate variables is estimated using linear regression analysis on the monthly and seasonal time series for snowfall, SCD and minimum, maximum and mean temperature for stations with no more than four consecutive or nonconsecutive years missing over the period 1965-2005. To account for the trend's sensitivity to the start and end date of the time series, we calculate the mean of the decadal rate of change estimated from linear regression of twelve 30-year windows with start dates ranging from 1965 to 1976 , and end dates ranging from 1994 to 2005 (e.g., for a window size of 30 years, trends were calculated for the time series 1965-1994, 1966-1995. . 1976-2005). The significance of trends is evaluated by computing p-values for Pearson's correlation of the time series, for which the assumption of normality was satisfied by inspecting residuals. Station trends with $p<$ 0.10 for all twelve 30 -year trends were considered statistically significant. 

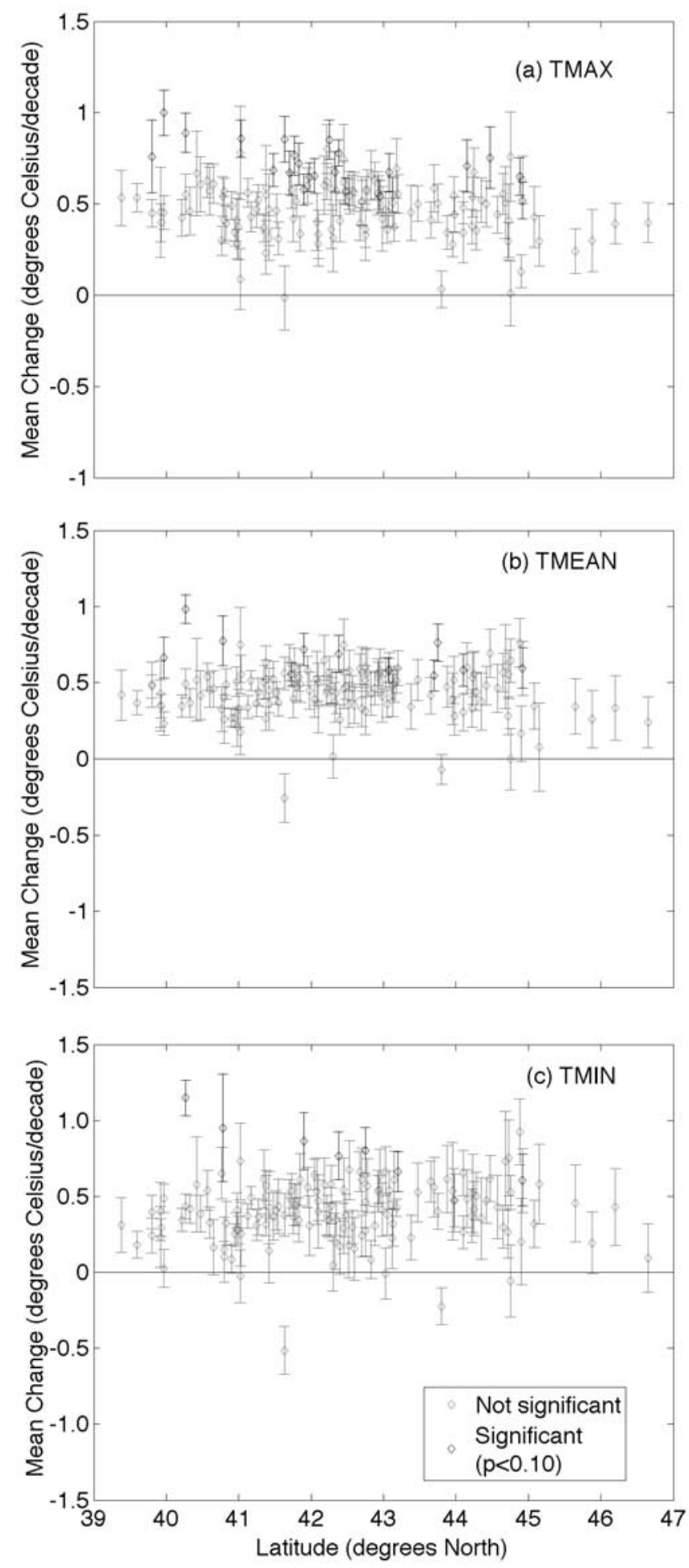

Figure 3. Decadal trends were calculated from twelve 30-year-window time series and average to obtain the mean decadal trend in winter (a) maximum, (b) mean, and (c) minimum temperature. Error bars are 1 standard deviation of mean trend. Statistically significant $(p<0.10)$ trends are shown in bold.

[14] Regional trends in winter climate were calculated by creating a spatially averaged anomaly time series from 1965 to 2005 for each variable. First, an anomaly time series of all stations within a climate division [Guttman and Quayle, 1996] is calculated by subtracting the 1965-2005 climatological seasonal or monthly mean. The station anomalies within a climate division are then averaged up to form a divisional time series, 1965-2005. A single region-wide mean is calculated from the divisional time series, weighted by NCDC climate division area. The mean regional trend is estimated from linear regression of twelve 30-year windows with start dates ranging from 1965 to 1976, and end dates 
Table 1. Summary of Regional Trends in Maximum, Minimum, and Mean Temperature, Snowfall, and Snow-Covered Days ${ }^{\mathrm{a}}$

\begin{tabular}{lccccc}
\hline & TMAX $\left({ }^{\circ} \mathrm{C} /\right.$ decade $)$ & TMIN $\left({ }^{\circ} \mathrm{C} /\right.$ decade $)$ & TMEAN $\left({ }^{\circ} \mathrm{C} /\right.$ decade $)$ & SNOW $(\mathrm{cm} /$ decade $)$ & SCD (days/decade) \\
\hline December & $+0.44 \pm 0.19$ & $+0.39 \pm 0.32$ & $+0.41 \pm 0.25$ & $-5.7 \pm 2.7$ & $-1.2 \pm 0.3$ \\
January & $+0.62 \pm 0.16$ & $+0.79 \pm 0.20$ & $+0.71 \pm 0.18$ & $+0.5 \pm 2.2$ & $-1.5 \pm 0.4$ \\
February & $+0.64 \pm 0.17$ & $+0.53 \pm 0.18$ & $+0.57 \pm 0.17$ & $-1.2 \pm 1.5$ & $-1.0 \pm 0.3$ \\
March & $+0.16 \pm 0.18$ & $-0.04 \pm 0.09$ & $+0.04 \pm 0.13$ & $+1.5 \pm 2.5$ & $0.0 \pm 0.7$ \\
Winter & $+0.46 \pm 0.09$ & $+0.42 \pm 0.14$ & $+0.43 \pm 0.12$ & $-4.6 \pm 4.3$ & $-3.6 \pm 1.3$ \\
\hline
\end{tabular}

${ }^{a}$ Maximum temperature, TMAX; minimum temperature, TMIN; mean temperature, TMEAN; snowfall, SNOW; snow-covered days, SCD. Regional trends were calculated by averaging up individual station anomalies within climate divisions to form divisional time series anomalies, then taking the areaweighted average of divisional time series anomalies.

ranging from 1994 to 2005 . The significance of trends is evaluated by computing p-values for Pearson's correlation of the time series, for which the assumption of normality was satisfied. A regional trend is considered statistically significant if $p<0.10$ is true for all twelve 30-year regionally averaged trends.

\section{Results and Discussion}

\subsection{Temperature}

[15] Over the period 1965-2005, the mean winter (December, January, February, March) temperature in the northeastern United States was $-2.6^{\circ} \mathrm{C} \pm 2.8^{\circ} \mathrm{C}$. Stations in the southern part of the region (New Jersey and Pennsylvania) and along the coast (Connecticut and Rhode Island) tend to have a mean winter temperature above freezing, while stations in the north (Maine, Massachusetts, New Hampshire, New York, and Vermont) are typically below freezing.

[16] Sensitivity analysis of maximum, minimum, and mean temperature records indicates that a winter warming trend is present across all latitudes in the NE-US (Figure 3). Regional winter maximum temperature increased $\left(+0.46^{\circ} \mathrm{C} /\right.$ decade) at a rate similar to that for regional winter minimum temperature $\left(+0.42^{\circ} \mathrm{C} /\right.$ decade $)$ and regional winter mean temperature $\left(+0.43^{\circ} \mathrm{C} /\right.$ decade) (Table 1$)$. Out of the 138 stations analyzed in the northeastern United States, 22 (7) stations showed statistically significant $(p<0.10)$ increasing trends in winter maximum (minimum) temperature for all of the twelve 30-year windows. No stations showed statistically significant decreasing trends in winter or monthly temperatures.

[17] The greatest monthly temperature increases in all three temperature measures occur in January and February (Table 1). Increases in February maximum $\left(+0.64^{\circ} \mathrm{C} /\right.$ decade) were greater than for minimum $\left(+0.53^{\circ} \mathrm{C} /\right.$ decade $)$ temperature, while the increase in January minimum temperature $\left(+0.79^{\circ} \mathrm{C} /\right.$ decade $)$ was greater than the increase in January maximum temperature $\left(+0.62^{\circ} \mathrm{C} /\right.$ decade $)$. For December and March, maximum temperatures are increasing at faster rates than minimum temperature.

[18] The variability of regionally averaged trends over time is evaluated with respect to the start- and end-year of the 30-year-window time series (Figure 4). Regional winter (DJFM) temperature trends exhibit warming trends regardless of the start year and end year of the 30-year time series window (Figure 4e). The magnitude of the warming trend for minimum, maximum, and mean temperature increases from the $1965-1994\left(0.17-0.35^{\circ} \mathrm{C} /\right.$ decade $)$ trend to the $1970-1999\left(0.57-0.60^{\circ} \mathrm{C} /\right.$ decade $)$ trend, followed by a decrease in the $1972-2001\left(0.38-0.39^{\circ} \mathrm{C} /\right.$ decade $)$ trend, which is weighted by colder than average winter temper- atures in 2001 . Trends return to $0.53-0.54^{\circ} \mathrm{C} /$ decade in 1973-2002 and remain relatively constant through 19762005. The trends in maximum temperature are significant for seven of the twelve 30-year windows. At the monthly level, December trends are increasing over time, with the exception of the 1972-2001 trend (Figure 4a). January and February exhibit warming trends regardless of the 30-yearwindow start and end year (Figures $4 \mathrm{~b}$ and $4 \mathrm{c}$ ). March temperature trends tend to decrease over time, ending with an overall cooling trend in minimum, maximum, and mean temperatures in the 1976-2005 time series (Figure 4d). Of the twelve time series analyzed, seven exhibited statistically significant $(p<0.10)$ trends in maximum, minimum, and mean seasonal (DJFM) temperature (Figure 4e). The regionally averaged monthly trends show far fewer significant trends than the overall wintertime average.

\subsection{Snow-Covered Days (SCD)}

[19] Over the period 1965-2005, stations near the coast and south of $42^{\circ} \mathrm{N}$ have typically experienced $0-60$ days with snow depth greater than $2.5 \mathrm{~cm}$, while stations north of $42^{\circ} \mathrm{N}$ typically have between 60 and 121 snow-covered days. We calculate the number of SCD by summing the number of days with snow depth greater than $0 \mathrm{~cm}$ (SCD0), $2.5 \mathrm{~cm}$ (SCD1), and $7.6 \mathrm{~cm}$ (SCD3). Only trends in SCD1 are presented; winter and monthly trends in SCD0, and SCD3 are very similar to the SCD1 results.

[20] Most stations in the northeastern United States have experienced an overall decrease in the total number of winter snow-covered days; however, only one individual station (Ebensburg, PA) trend was found to be statistically significant for all twelve 30-year time series (Figure 5). The regional average decrease in total seasonal SCD1 ( -3.6 days/decade) is largely the result of decreases during the months of December, January, and February. Statistically significant regional trends were found in winter SCD1 trends (Table 2). Acknowledging the lack of significance in individual station trends, the decreases in December, January, and February snow-covered days coincide with strong increases in maximum and minimum temperature (Table 1).

[21] The presence of snow cover may depend more on temperature and less on snowfall, which has also been suggested by Lemke et al. [2007] and Hayhoe et al. [2007]. In addition, the documented decrease in the S/P ratio [Huntington and Hodgkins, 2004] suggests that increasing winter rainfall over the period 1949-2000 may also be involved in melting shallow snow cover and exposing bare ground. Further analysis with additional regional climate modeling is required to better investigate the causal link between the increases in temperature and 

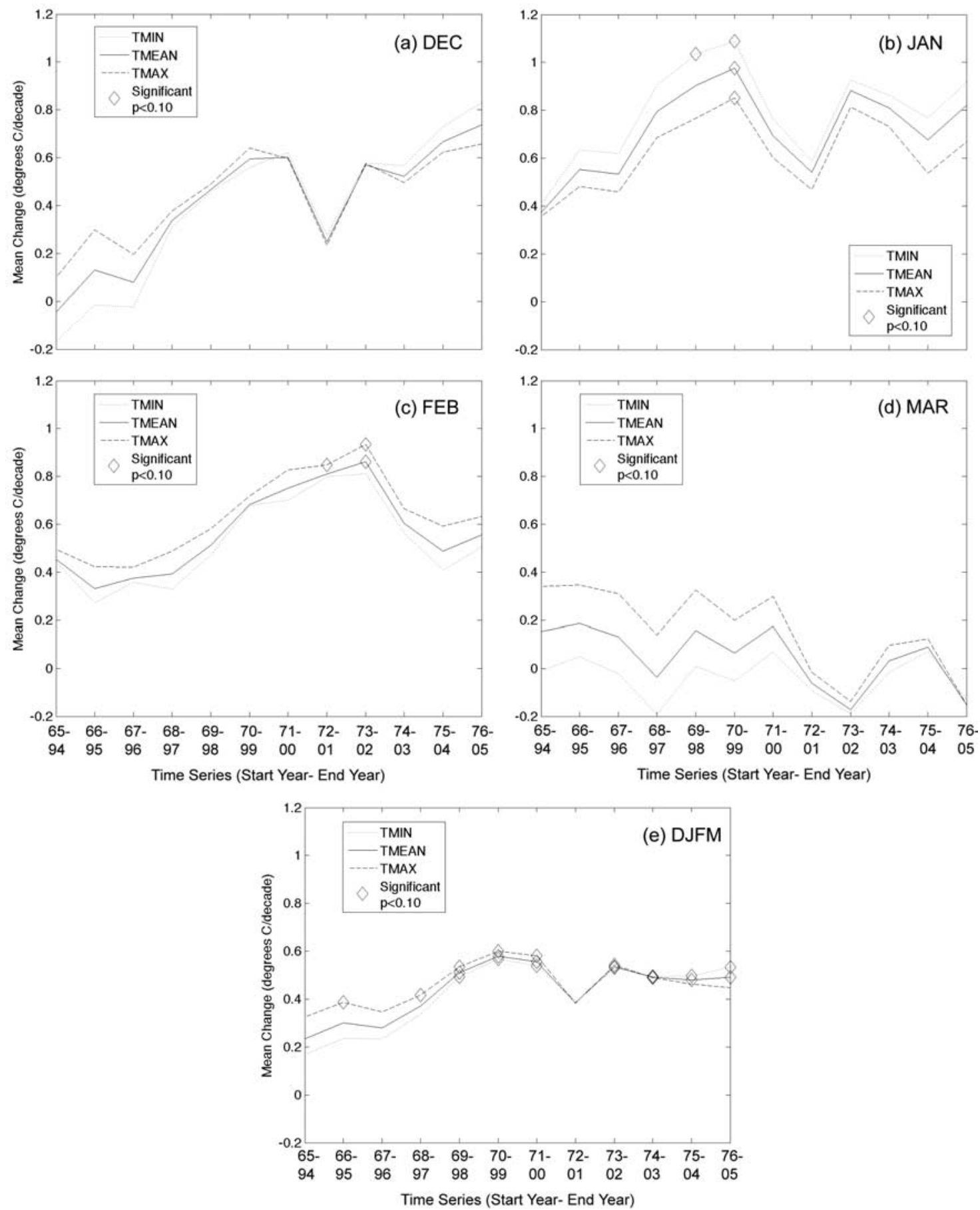

Figure 4. Change in magnitude of regionally averaged monthly temperature trends for (a) December, (b) January, (c) February, (d) March, and (e) winter as calculated from linear regression of twelve 30-year time series windows from the period 1965-2005. Statistically significant $(\mathrm{p}<0.10)$ trends are marked with diamonds.

reduction in snow cover during the coldest winter months of January and February.

\subsection{Snowfall}

[22] The mean total winter (December, January, February, and March) snowfall at stations in the NE-U.S. ranges from $34.3 \mathrm{~cm}$ (Cape May, NJ) to $349.5 \mathrm{~cm}$ (Oswego, NY). High-elevation stations (>3000 ft ASL) such as Mount
Mansfield, VT and Mount Washington, NH are excluded from regional snowfall trend analysis for two reasons: (1) lack of comparable neighboring stations make it difficult to check for spatial coherence, and (2) high-elevation stations are subject to both boundary layer and free air processes and therefore may not represent regional trends. Total snowfall during the winter months has decreased at stations across much of the northeastern U.S. over the period 

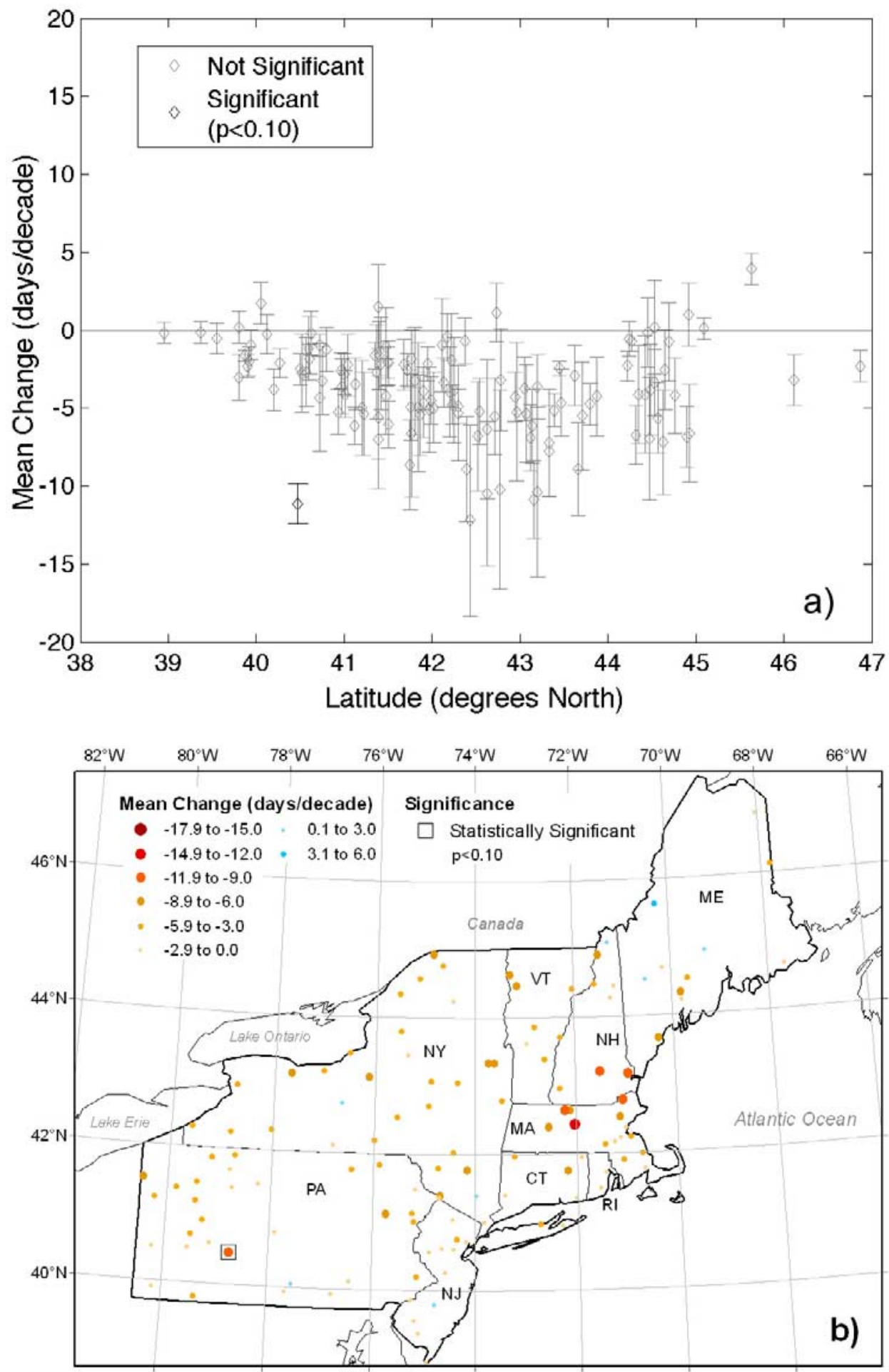

Figure 5. Mean decadal rate of change in winter snow-covered days (snow depth $>2.54 \mathrm{~cm}$ ), by (a) station latitude and (b) station location. On map, size of dot indicates magnitude and color represents direction (warming is red; cooling is blue) of trend.

1965-2005, though no stations were found to have significant trends (Figure 6).

[23] Stations with increasing winter snowfall trends tend to be located primarily near the Great Lakes, though this is not true of all stations downwind of the Great Lakes (Figure 6b). Analysis of air temperature, water temperature, and lake ice records in the vicinity of the Great Lakes suggest that observed increases in lake-effect snow during 
Table 2. Summary of Sensitivity Analysis of Snowfall and Snow-Covered Days Trends ${ }^{\mathrm{a}}$

\begin{tabular}{|c|c|c|c|c|c|c|c|c|c|c|}
\hline \multirow[b]{2}{*}{ Time Series } & \multicolumn{5}{|c|}{ Snowfall $(\mathrm{cm} /$ decade $)$} & \multicolumn{5}{|c|}{ Snow-Covered Days (days/decade) } \\
\hline & Dec & Jan & Feb & Mar & Winter & Dec & Jan & Feb & Mar & Winter \\
\hline $1965-1994$ & -6.4 & +1.4 & -1.6 & +0.1 & -6.3 & -0.9 & -1.5 & -0.7 & -0.2 & -3.2 \\
\hline $1966-1995$ & -8.2 & +0.5 & -2.0 & -1.3 & -10.7 & -1.2 & -1.9 & -0.9 & -0.7 & -4.6 \\
\hline $1967-1996$ & -7.9 & +4.1 & -2.0 & -1.4 & -7.0 & -0.9 & -1.8 & -1.0 & -0.9 & -4.5 \\
\hline $1968-1997$ & -7.9 & +3.2 & -1.1 & 0.0 & -5.7 & -1.3 & -2.0 & -1.0 & -0.5 & -4.7 \\
\hline $1969-1998$ & -7.9 & +2.4 & -3.8 & -0.2 & -9.5 & -1.2 & -1.9 & -1.3 & -0.6 & -4.9 \\
\hline $1970-1999$ & -8.9 & +2.3 & -3.0 & +0.6 & -8.9 & -1.7 & -1.7 & -1.6 & -0.2 & -5.1 \\
\hline $1971-2000$ & -7.7 & +1.4 & -2.7 & 0.0 & -8.9 & -1.8 & -1.5 & -1.3 & -0.2 & -4.7 \\
\hline $1972-2001$ & -3.8 & +0.3 & -1.3 & +4.8 & +0.3 & -1.2 & -0.7 & -1.0 & +0.7 & -2.2 \\
\hline $1973-2002$ & -5.3 & -1.2 & +0.1 & +5.4 & -0.7 & -1.6 & -1.1 & -1.1 & +0.9 & -3.0 \\
\hline $1974-2003$ & -2.6 & -2.3 & +1.1 & +3.3 & +0.1 & -0.9 & -1.2 & -0.7 & +0.8 & -2.1 \\
\hline $1975-2004$ & -0.7 & -2.9 & +0.1 & +3.1 & -0.1 & -0.9 & -1.1 & -0.7 & +0.4 & -2.4 \\
\hline $1976-2005$ & -1.7 & -2.4 & +1.1 & +4.2 & +1.4 & -0.9 & -1.2 & -0.5 & +0.7 & -1.9 \\
\hline Average & $-5.8 \pm 2.7$ & $+0.5 \pm 2.2$ & $-1.2 \pm 1.5$ & $+1.5 \pm 2.5$ & $-4.6 \pm 4.3$ & $-1.2 \pm 0.3$ & $-1.5 \pm 0.4$ & $-1.0 \pm 0.3$ & $0.0 \pm 0.7$ & $-3.6 \pm 1.3$ \\
\hline
\end{tabular}

${ }^{a}$ Trends were evaluated using linear regression over twelve 30 -year time series over the period $1965-2005$. Statistically significant $(p<0.10)$ trends are shown in bold.

the twentieth century may be the result of warmer Great Lakes surface water temperature and decreased ice cover [Burnett et al., 2003]. Annual maximum ice cover over the period 1998-2001 is the lowest four-winter average over the period 1963-2001, and Lake Erie was virtually ice-free in 1998 [Assel et al., 2003]. Additional analysis and modeling is likely necessary to establish a causal relationship between increasing snowfall at some stations downwind of the Great Lakes to an increase in lake-effect snow.

[24] On the basis of the individual station and regional trend analysis, snowfall trends can be characterized by an overall decrease $(-4.6 \mathrm{~cm} /$ decade $)$ in winter snowfall (Table 1). The reduction in winter snowfall occurs primarily as strong decreases in December $(-5.8 \mathrm{~cm} /$ decade $)$ and weak decreases in February $(-1.3 \mathrm{~cm} /$ decade). Seven of the twelve 30 -year time series in the sensitivity analysis for December snowfall were found to be statistically significant decreasing trends (Table 2).

[25] The snowfall data for the COOP and USHCN data analyzed here compliment the decreasing trend in the snow to total precipitation $(\mathrm{S} / \mathrm{P})$ ratio identified in the work of Huntington and Hodgkins [2004], in which annual (S/P) trends were predominantly the result of decreasing snowfall over the period 1949-2000, and to a lesser extent increasing rainfall. Other studies of snow data in the northeastern United States also report decreasing trends in snowfall and snow water equivalent over the period 1900-1999, with stronger decreases over the period 1970-1999 [Hayhoe et al., 2007; Hodgkins and Dudley, 2006a, Hamilton et al., 2003]. Although nonclimatic influences may exist in USHCN and COOP data, the care taken in this study to remove stations with such biases from the analysis provides greater confidence in the snowfall results presented here. High interannual variability in winter snowfall, as well as the documented decrease in the snow to total precipitation ratio [Huntington and Hodgkins, 2004] complicate interpretation of snowfall trends. For example, some of the decreasing trends in snowfall may be due to greater compaction of denser snow, although at least one study has found a decreasing trend in snow water equivalent based on output from the Variable Infiltration Capacity model [Liang et al., 1994, 1996; Cherkauer et al., 2003] input with downscaled observed temperature and precipitation fields [Hayhoe et al., 2007].

\section{Conclusions}

[26] In this study, extensive quality assurance and quality control measures were taken to ensure that only the best available meteorological data were used to document trends in wintertime climate in the northeastern United States. Missing data values and incomplete documentation of station moves, instrument changes, and observer changes complicate trend analysis of climate data. Stringent and consistent operational practices among USHCN and COOP stations would improve the certainty of trends derived from the observational record. Time series analysis of temperature, snowfall, and snow-covered days indicate a regionwide winter warming trend in the northeastern United States over the period 1965-2005, a period during which global and northern hemisphere surface air temperature increases are being driven primarily by enhanced levels of anthropogenic greenhouse gases in the atmosphere [Brohan et al., 2006; Hansen et al., 2006; Solomon et al., 2007].

[27] Winter temperatures have increased substantially in the northeastern United States, with the most warming occurring in the months of January and February for minimum, mean, and maximum temperatures. Statistically significant decreasing trends in monthly snowfall were identified in December records. December, January, and February have also experienced decreasing trends in snowcovered days, and some trends were found to be statistically significant. The synchronous timing of warmer temperatures and the decrease in snow-covered days suggest that the two trends may be linked via the snow-albedo feedback loop. Additional analysis using a regional climate model is required to quantify the extent to which the snow-albedo feedback may be enhancing changes in winter temperature and snow-covered days. Regional climate models are one of the most promising tools for projecting climate changes into the future and assessing regional impacts. A regional climate modeling system (RCMS) that coupled the Penn State/ NCAR MM5 atmospheric component with the land surface transfer model [Pollard and Thompson, 1995] accurately predicted precipitation trends over the period 1991-1999 for 

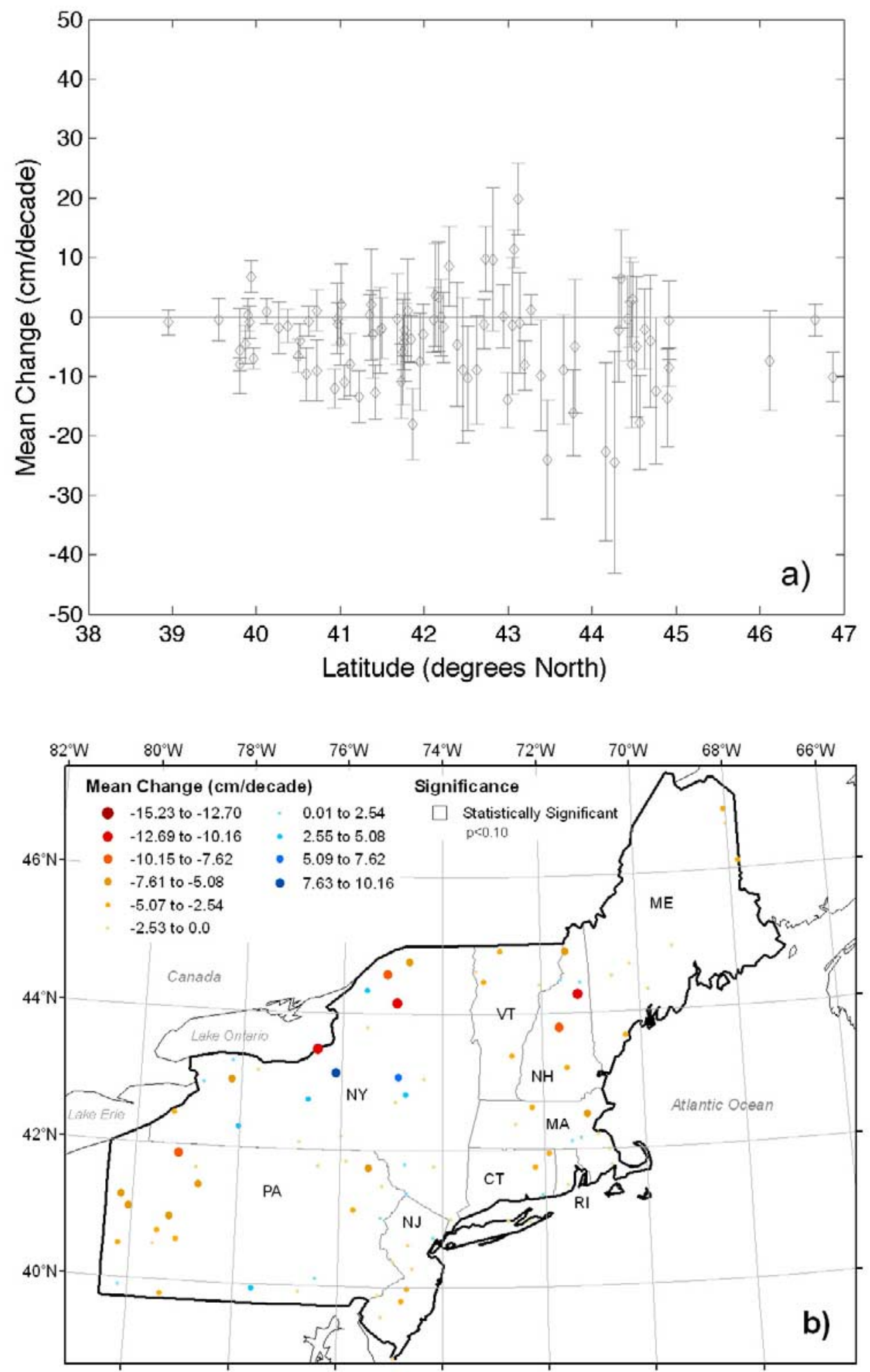

Figure 6. Mean decadal rate of change in winter snowfall, by (a) station latitude and (b) station location. In Figure 6b, size of dot indicates magnitude and color represents direction (warming, red; cooling, blue) of trend.

the northeastern United States [Chen et al., 2005]. The use of a similar RCMS setup will be utilized to generate regional trends in snowfall and snow cover, and to investigate the possible link between snow cover and temperature.
[28] Although trends in snow-covered days at individual stations are important, they only provide a proxy measure of changes in snow cover area. Improved quantification of trends in regional snow cover extent are necessary to better 
understand the region's sensitivity to changes in surface albedo. Satellite imagery combined with station observations revealed a decreasing trend in spring snow cover extent over North America since the 1980s [Frei et al., 1999]. Future work will focus on identifying trends in snow cover area through the use of daily snow cover maps available at the Rutgers University Global Snow Lab, and comparing the satellite-derived trends to snow cover output from regional climate models of the northeastern United States. In addition, the introduction of high-resolution (500 m) daily satellite snow maps from NASA's Earth Observing System Moderate Resolution Imaging Spectroradiometer (MODIS) in February 2000 will be useful in creating a high-quality time series of snow cover extent for future studies at the regional scale.

[29] These documented changes in wintertime climate have and will continue to impact the region's natural ecosystems, hydrology and winter tourism industry. For example, decreases in the number of snow-covered days impact the northeastern United States' multibillion dollar winter tourism and recreation industry. Collectively, the skiing and snowmobiling industry contributes approximately 7.6 billion dollars annually to the northeastern U.S. economy [Scott and McBoyle, 2007]. While the skiing industry has been able to adapt to winters with less snow cover by incorporating artificial snowmaking, the snowmobiling, cross-country skiing and ice fishing industries do not have such adaptive capacity. The magnitude of future warming and reduction of snow cover and snowfall in the northeast United States, and the resulting impacts on regional ecosystems, hydrology and winter recreation will likely be determined by the greenhouse gas emissions pathway we follow over the next several decades [Frumhoff et al., 2008; Hayhoe et al., 2007; Scott and McBoyle, 2007].

[30] Acknowledgments. The authors would like to thank David Robinson for helpful conversations regarding snowfall data, and two anonymous reviewers for their comments which greatly improved the manuscript. This research was supported by the Atmospheric Investigation, Regional Modeling, Analysis and Prediction (AIRMAP) Project which is funded by NOAA's Office of Oceanic and Atmospheric Research (grants NA05OAR4601080 and NA06OAR4600189) and by the UNH Department of Earth Sciences.

\section{References}

Assel, R., K. Cronk, and D. Norton (2003), Recent trends in Laurentian Great Lakes ice cover, Clim. Change, 57, 185-204, doi:10.1023/ A:1022140604052.

Baker, D. G., D. L. Ruschy, R. H. Skaggs, and D. B. Wall (1992), Air temperature and radiation depressions associated with snow cover, J. Appl. Meteorol., 31, 247-254, doi:10.1175/1520-0450(1992)031 $<0247$ :ATARDA $>2.0 . \mathrm{CO} ; 2$.

Brohan, P., J. J. Kennedy, I. Harris, S. F. B. Tett, and P. D. Jones (2006), Uncertainty estimates in regional and global observed temperature changes: A new data set from 1850, J. Geophys. Res., 111, D12106, doi:10.1029/2005JD006548.

Brown, R. D. (2000), Northern Hemisphere snow cover variability and change 1915-1997, J. Clim., 13, 2339-2355, doi:10.1175/15200442(2000)013<2339:NHSCVA>2.0.CO;2.

Burnett, A. W., M. E. Kirby, H. T. Mullins, and W. P. Patterson (2003), Increasing Great Lake-Effect snowfall during the twentieth century: A regional response to global warming?, J. Clim., 16, 3535-3542, doi:10.1175/1520-0442(2003)016<3535:IGLSDT>2.0.CO;2.

Chen, M., H. Mao, R. Talbot, and D. Pollard (2005), Changes in precipitation characteristics over North America for doubled $\mathrm{CO}_{2}$, Geophys. Res. Lett., 32, L19716, doi:10.1029/2005GL024535.
Cherkauer, K. A., L. C. Bowling, and D. P. Lettenmaier (2003), Variable infiltration capacity cold land process model updates, Global Planet. Change, 38, 151-159, doi:10.1016/S0921-8181(03)00025-0.

Déry, S. J., and R. D. Brown (2007), Recent Northern Hemisphere snow cover extent trends and implications for the snow-albedo feedback Geophys. Res. Lett., 34, L22504, doi:10.1029/2007GL031474.

Dewey, K. F. (1977), Daily maximum and minimum temperature forecasts and the influence of snow cover, Mon. Weather Rev., 105, 1594-1597, doi:10.1175/1520-0493(1977)105<1594:DMAMTF>2.0.CO;2.

Doesken, N. J., and A. Judson (1996), The Snow Booklet: A Guide to the Science, Climatology and Measurement of Snow in the United States, 84 pp., Dep. of Atmos. Sci., Colo. State Univ., Fort Collins, Colo.

Dyer, J. L., and T. L. Mote (2006), Spatial variability and trends in observed snow depth over North America, Geophys. Res. Lett., 33, L16503, doi:10.1029/2006GL027258.

Easterling, D. R., T. R. Karl, J. H. Lawrimore, S. A. Del Greco (1999), United States historical climatology network daily temperature, precipitation, and snow data for 1871-1997, ORNL/CDIAC-118, NDP-070, Carbon Dioxide Inf. Anal. Cent., Oak Ridge Natl. Lab., U.S. Dep. of Energy, Oak Ridge, Tenn.

Frei, A., D. A. Robinson, and M. G. Hughes (1999), North American snow extent: 1900-1994, Int. J. Climatol., 19, 1517-1534, doi:10.1002/ (SICI)1097-0088 (19991130)19:14<1517::AID-JOC437>3.0.CO;2-I.

Frumhoff, P. C., J. J. McCarthy, J. M. Melillo, S. C. Moser, D. J. Wuebbles, C. P. Wake, and E. Spanger-Siegfried (2008), An integrated climate change assessment for the northeast United States, Mitig. Adapt. Strat. Global Change, doi:10.1007/s11027-007-9138-x, in press.

Groisman, P., T. R. Karl, and R. W. Knight (1994), Observed impact of snow cover on the heat balance and the rise of continental spring temperatures, Science, 263(5144), 198-200, doi:10.1126/science.263.5144.198.

Guttman, N. B., and R. G. Quayle (1996), A historical perspective of U.S. climate divisions, Bull. Am. Meteorol. Soc., 77, 293-301, doi:10.1175/ 1520-0477(1996)077<0293:AHPOUC >2.0.CO;2.

Hamilton, L. C., D. E. Rohall, C. Brown, G. Hayward, and B. D. Keim (2003), Warming winters and New Hampshire's lost ski areas: An integrated case study, Int. J. Sociol. Soc. Policy, 23, 52-73, doi:10.1108/ 01443330310790309 .

Hamilton, L. C., C. Brown, and B. D. Keim (2007), Ski areas, weather and climate: Time series models for New England case studies, Int. J. Climatol., 27, 2113-2124, doi:10.1002/joc. 1502 .

Hansen, J., M. Sato, R. Ruedy, K. Lo, D. W. Lea, and M. Medina-Elizade (2006), Global temperature change, Proc. Natl. Acad. Sci. U. S. A., 103, 14,288-14,293, doi:10.1073/pnas.0606291103.

Hayhoe, K., et al. (2007), Past and future changes in climate and hydrological indicators in the US northeast, Clim. Dyn., 28, 381-407, doi:10.1007/s00382-006-0187-8.

Hodgkins, G. A., and R. W. Dudley (2006a), Changes in late-winter snowpack depth, water equivalent, and density in Maine, 1926-2004, Hydrol. Processes, 20, 741-751, doi:10.1002/hyp.6111.

Hodgkins, G. A., and R. W. Dudley (2006b), Changes in the timing of winter-spring high streamflows in eastern North America 1912-2002, Geophys. Res. Lett., 33, L06402, doi:10.1029/2005GL025593.

Hodgkins, G. A., I. C. James, and T. G. Huntington (2002), Historical changes in ice-out dates as indicators of climate change in New England, Int. J. Climatol., 22, 1819-1827, doi:10.1002/joc.857.

Hodgkins, G. A., R. W. Dudley, and T. G. Huntingon (2003), Changes in the timing of high river flows in New England over the 20th century, J. Hydrol., 278, 244-252, doi:10.1016/S0022-1694(03)00155-0.

Hughes, M. G., and D. A. Robinson (1993), Creating temporally complete snow cover records using a new method for modeling snow depth changes, in Snow Watch '92: Detection Strategies for Snow and Ice, Glaciol. Data Rep. GD-25, pp. 150-163, Natl. Snow and Ice Data Cent., Boulder, Colo.

Huntington, T. G., and G. A. Hodgkins (2004), Changes in the proportion of precipitation occurring as snow in New England (1949-2000), J. Clim. 17, 2626-2636, doi:10.1175/1520-0442(2004)017<2626:CITPOP $>$ 2.0.CO;2.

Huntington, T. G., G. A. Hodgkins, and R. W. Dudley (2003), Historical trend in river ice thickness and coherence in hydroclimatological trends in Maine, Clim. Change, 61, 217-236, doi:10.1023/A:1026360615401.

Karl, T. R., and C. N. Williams Jr. (1987), An approach to adjusting climatological time series for discontinuous inhomogeneities, J. Appl. Meteorol., 26, 1744-1763, doi:10.1175/1520-0450(1987)026<1744:AATACT >2.0. $\mathrm{CO} ; 2$

Karl, T. R., C. N. Williams Jr., P. J. Young, and W. M. Wendland (1986), A model to estimate the time of observation bias associated with monthly mean maximum, minimum, and mean temperatures for the United States, J. Appl. Meteorol., 25, 145-160, doi:10.1175/1520-0450(1986)025 $<0145$ :AMTETT>2.0.CO;2. 
Karl, T. R., H. F. Diaz, and G. Kukla (1988), Urbanization: Its detection and effect in the United States climate record, J. Clim., 1, 1099-1123, doi:10.1175/1520-0442(1988)001<1099:UIDAEI >2.0.CO;2.

Karl, T. R., C. N. Williams Jr., F. T. Quinlan, and T. A. Boden (1990), United States Historical Climatology Network (HCN) serial temperature and precipitation data, Environ. Sci. Div. Publ. 3404, 389 pp., Carbon Dioxide Inf. and Anal. Cent., Oak Ridge Natl. Lab., U. S. Dep. of Energy, Oak Ridge, Tenn.

Keim, B. D., A. M. Wilson, and T. G. Huntington (2003), Are there spurious temperature trends in the United States Climate Division database? Geophys. Res. Lett., 30(7), 1404, doi:10.1029/2002GL016295.

Kunkel, K. E., M. A. Palecki, K. G. Hubbard, D. A. Robinson, K. T. Redmond, and D. R. Easterling (2007), Trend identification in twentieth-century U.S. snowfall: The challenges, J. Atmos. Oceanic Technol., 24, 64-73, doi:10.1175/JTECH2017.1.

Leathers, D. J., and B. L. Luff (1997), Characteristics of snow cover duration across the northeast United States of America, Int. J. Climatol., 17, 1535-1547, doi:10.1002/(SICI)1097-0088(19971130)17:14<1535::AIDJOC215>3.0.CO;2-7.

Leathers, D. J., and D. A. Robinson (1993), The association between extremes in North American snow cover extent and United States temperatures, J. Clim., 6, 1345-1355, doi:10.1175/1520-0442(1993)006<1345:TABEIN > 2.0.CO;2.

Leathers, D. J., A. W. Ellis, and D. A. Robinson (1995), Characteristics of temperature depressions associated with snow cover across the northeast United States, J. Appl. Meteorol., 34, 381-390.

Lemke, P., et al. (2007), Observations: Changes in snow, ice and frozen ground, in Climate Change 2007: The Physical Science Basis-Contributions of Working Group I to the Fourth Assessment of the Intergovernmental Panel on Climate Change, edited by S. Solomon et al., pp. 337-384, Cambridge Univ. Press, Cambridge, U.K.

Liang, X., D. P. Lettenmaier, E. F. Wood, and S. J. Burges (1994), A simple hydrologically based model of land surface water and energy fluxes for GCMs, J. Geophys. Res., 99(D7), 14,415-14,428, doi:10.1029/ 94JD00483.

Liang, X., E. F. Wood, and D. P. Lettenmaier (1996), Surface soil moisture parameterization of the VIC-2L model: Evaluation and modifications, Global Planet. Change, 13, 195-206, doi:10.1016/0921-8181(95)00046-1.

National Ski Areas Association (2006), Kottke National End of Season Survey 2005/06, final report, Lakewood, Colo.

Pollard, D., and S. L. Thompson (1995), Use of land-surface-transfer scheme (LSX) in a global climate model: The response to doubling stomatal resistance, Global Planet. Change, 10, 129-161, doi:10.1016 0921-8181(94)00023-7.

Quayle, R. G., D. R. Easterling, T. R. Karl, and P. Y. Hughes (1991), Effects of recent thermometer changes in the cooperative station network, Bull. Am. Meteorol.
Soc., 72, 1718-1724, doi:10.1175/1520-0477(1991)072<1718:EORTCI>2.0. $\mathrm{CO} ; 2$

Roebber, P. J., S. L. Bruening, D. M. Schultz, and J. V. Cortinas Jr. (2003), Improving snowfall forecasting by diagnosing snow density, Weather Forecast., 18, 264-287, doi:10.1175/1520-0434(2003)018<0264:ISFBDS >2.0.CO;2.

Scott, D., and G. McBoyle (2007), Climate change adaptation in the ski industry, Mitig. Adapt. Strat. Global Change, 12(8), 1411-1431, doi:10.1007/s11027-006-9071-4.

Solomon, S., et al. (2007), Technical summary, in Climate Change 2007: The Physical Science Basis - Contribution of Working Group I to the Fourth Assessment Report of the Intergovernmental Panel on Climate Change, edited by S. Solomon et al., pp. 19-91, Cambridge Univ. Press, Cambridge, U.K.

Trombulak, S. C., and R. Wolfson (2004), Twentieth-century climate change in New England and New York, USA, Geophys. Res. Lett., 31, L19202, doi:10.1029/2004GL020574.

Wake, C. P., E. Burakowski, and L. Goss (2006), Winter recreation and climate variability in New Hampshire: 1984-2006, Clean Air-Cool Planet, Portsmouth, N. H. (Available at http://www.carboncoalition.org/ education/documents/NHWinterTourismandClimateVariability Feb 2007.pdf)

Williams, C. N., Jr., M. J. Menne, R. S. Vose, and D. R. Easterling (2005), United states historical climatology network monthly temperature and precipitation data, ORNL/CDIAC-118, NDP- 019, http://cdiac.ornl.gov/ epubs/ndp/ushen/usa_monthly.html, Carbon Dioxide Inf. Anal. Cent., Oak Ridge Natl. Lab., U.S. Dep. of Energy, Oak Ridge, Tenn.

Williams, C. N., Jr., M. J. Menne, R. S. Vose, and D. R. Easterling (2006), United States Historical Climatology Network daily temperature, precipitation, and snow data, ORNL/CDIAC-118, NDP-070, http://cdiac.ornl. gov/epubs/ndp/ushen/usa.html, Carbon Dioxide Inf. Anal. Cent., Oak Ridge Natl. Lab., U.S. Dep. of Energy, Oak Ridge, Tenn.

Wolfe, D. W., M. D. Schwarz, A. Lakso, Y. Otsuki, R. Pool, and N. Shaulis (2005), Climate change and shifts in spring phenology of three horticultural woody perennials in the northeastern USA, Int. J. Biometeorol., 49, 303-309, doi:10.1007/s00484-004-0248-9.

B. Braswell, Complex Systems Research Center, Institute for the Study of Earth, Oceans, and Space, University of New Hampshire, Durham, NH 03824, USA.

D. P. Brown, Department of Geography and Anthropology, Louisiana State University, Baton Rouge, LA 70803, USA.

E. A. Burakowski and C. P. Wake, Climate Change Research Center, Institute for the Study of Earth, Oceans, and Space, and Department of Earth Sciences, University of New Hampshire, 56 College Road, James Hall, Durham, NH 03824, USA. (elizabeth.burakowski@gmail.com) 